See Article page 261.

\section{Commentary: Despair and disparity}

\author{
Zane T. Hammoud, MD, FACS
}

Lung cancer, even when completely resected, remains a deadly disease. The role of adjuvant therapy for $\mathrm{pN} 1$ or $\mathrm{pN} 2$ disease is well established. The efficacy of such therapy is based on solid evidence, and such adjuvant therapy is recommended by National Comprehensive Cancer Network (NCCN) guidelines. However, for a variety of reasons, not all patients who meet the criteria for adjuvant therapy receive such therapy. This is a critical issue, for the indications for adjuvant therapy after lung resection are likely to expand in the future.

In this issue of the Journal, Farrow and colleagues ${ }^{1}$ attempt to determine factors underlying treatment disparities in this specific set of patients. Using the National Cancer Data Base, the authors identified 13,462 patients with cT1-3N0-1 non-small cell lung cancer who underwent R0 resection without induction therapy and found to have $\mathrm{pN} 1$ or $\mathrm{pN} 2$ disease. They identify those patients in whom NCCN guideline therapy was administered (concordant group) and those in whom NCCN guideline therapy was not administered (discordant group) and examine those factors underlying the treatment disparities between the 2 groups. As reported, guideline concordant therapy improves survival. Thus, identifying (and addressing) factors leading to disparities in such therapy may ultimately lead to improvement in overall survival in this group of patients.

Gratifyingly, the authors found that nearly $70 \%$ of patients overall received guideline concordant therapy. This compares favorably with other types of cancer. Furthermore, the percentage of patients receiving guideline concordant therapy increased during the latter years of the study, perhaps suggesting that we're doing better. These results are encouraging, but there is obviously room for improvement. Of the variety of factors identified which may account

\footnotetext{
From the Division of Thoracic Surgery, Henry Ford Hospital, Detroit, Mich.

Disclosures: Author has nothing to disclose with regard to commercial support.

Received for publication Oct 28, 2019; accepted for publication Oct 29, 2019; available ahead of print Nov 22, 2019.

Reprint requests: Zane T. Hammoud, MD, FACS, Division of Thoracic Surgery, Henry Ford Hospital, 2799 West Grand Boulevard, k-14, Detroit, MI 48202 (E-mail: zhammou1@hfhs.org).

J Thorac Cardiovasc Surg 2020;160:275

0022-5223/ $\$ 36.00$

Copyright (c) 2019 by The American Association for Thoracic Surgery

https://doi.org/10.1016/j.jtcvs.2019.10.190
}

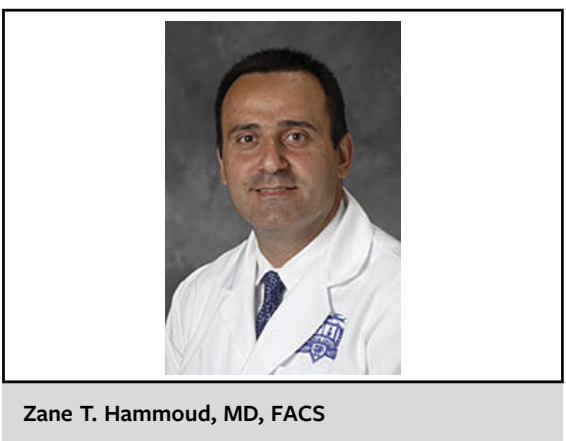

CENTRAL MESSAGE

Insurance status is a leading factor in guideline discordant therapy for completely resected $\mathrm{pN}_{1}$ and pN2 non-small cell lung cancer.

for disparities in treatment, race was not found to be significant, again suggesting that we are doing better in this regard. The other "usual suspects" of age, extent of surgery, and socioeconomic status, among others, are notable for their impact on treatment disparity.

Among the various factors accounting for treatment disparity, the one that arguably can be most controlled is insurance status. For, as is well known, lack of health insurance is a major determinant in the provision of appropriate care. Reports like the one by Farrow and colleagues continue to highlight the importance of insurance status on overall patient outcomes. Some things, such as age, socioeconomic status, and even geography, are beyond control, whereas others, like insurance status, are not. We must focus on things over which we have some control. Lack of health insurance during time of need may lead to a sense of despair. As patient advocates, we must not give in to despair and continue to push our policy makers to improve health insurance access to all of our patients, for, as this well-written report shows, their survival depends on it.

\section{Reference}

1. Farrow NE, An SJ, Speicher PJ, Harpole DH, D'Amico TA, Klapper JA, et al. Disparities in guideline-concordant treatment for node-positive, non-small cell lung cancer following surgery. J Thorac Cardiovasc Surg. 2020;160: 261-71.e1. 